\title{
The value of the FDG-GaTate and proliferation marker (ki-67) in the assessment of neuroendocrine tumours (NETs)
}

\author{
AS Fathinul Fikri' ${ }^{1 *}, J N$ Abdul ${ }^{1}$, S Ramdave ${ }^{2}$, R Syafik-Eid ${ }^{2}$ \\ From International Cancer Imaging Society Meeting and 15th Annual Teaching Course (ICIS 2015) \\ London, UK. 5-7 October 2015
}

\begin{abstract}
Aims
A combined tracer evaluation of Ga-68 DOTATATE (GaTate) and F-18 FDG (FDG) positron emission tomography (PET-CT) and the ki-67 marker have potential advantages over a single marker in determining the differentiation of NETs. This study is sought to evaluate their association and the potential role as predictive markers for the management impact.
\end{abstract}

\section{Methods}

Twenty-one combined FDG-GaTate studies were performed in various NETs lineages. A retrospective blinded review was performed based on the grade of tumour differentiation of ki-67 (European NET Society-ENETS) and the correlated Krenning scales (Grade 1-4) of the FDGGaTATE PET-CT images. Subsequent management impact (high and low) was determined by follow-up to assess metabolic response of the pre and post treatment GATATE-FDG PET-CT results.

\section{Results}

Significant correlation were noted in the Ki-67 (mean: 6.16 $\pm 8.21 \%$ ) and the FDG SUVmax (mean: $5.72 \pm 5.24 ; \mathrm{g} / \mathrm{dl} \mathrm{p}<$ 0.01 ) and inversely correlated with the Ga SUVmax (mean: $15.80 \pm 10.57 \mathrm{~g} / \mathrm{dl} ; \mathrm{p}<0.05)$. Management impact in $12 / 21$ patients was high (partial metabolic response or no recurrence) in $75 \%$ and low in $25 \%$ (progressive metabolic disease). The combined ki-67-GaTATE marker had independent predictive significance for management impact (likelihood ratio test for the whole model, $\mathrm{p}=0.008)$.

* Correspondence: ahmadsaadff@gmail.com

${ }^{1}$ Centre for Diagnostic Nuclear Imaging, Serdang, Selangor, Malaysia

Full list of author information is available at the end of the article

\section{Conclusion}

Dual-tracer assessment of FDG-GaTate PET-CT provide a valuable information on the NETs' cellular differentiation. Combination of ki-67-GaTATE may potentially be used as a reliable predictive marker for the NETs' management impact.

\section{Authors' details \\ 'Centre for Diagnostic Nuclear Imaging, Serdang, Selangor, Malaysia. ${ }^{2}$ PET Centre, Moorabbin Hospital, MonashHealth, Melbourne, Australia.}

Published: 2 October 2015

doi:10.1186/1470-7330-15-S1-P53

Cite this article as: Fikri et al:: The value of the FDG-GaTate and proliferation marker (ki-67) in the assessment of neuroendocrine tumours (NETs). Cancer Imaging 2015 15(Suppl 1):P53.

\footnotetext{
Submit your next manuscript to BioMed Central and take full advantage of:

- Convenient online submission

- Thorough peer review

- No space constraints or color figure charges

- Immediate publication on acceptance

- Inclusion in PubMed, CAS, Scopus and Google Scholar

- Research which is freely available for redistribution

Submit your manuscript at www.biomedcentral.com/submit
} 